\title{
Evaluation of degradation of organophosphate insecticide residues in stored corn (Zea mays L.) grains
}

Strada, J., Bruno, C., Nassetta, M. M., Balzarini, M. G., Conles, M. Y., Rojas, D., Ricca, A. P., Cristos, D., and Martinez, M. J.

DOI: $10.31047 / 1668.298 x . v 38 . n 2.30806$

\begin{abstract}
SUMMARY
The aims of this work were to monitor the dissipation dynamics of the organophosphate insecticides applied to corn grains stored in supervised experiments, establish the dissipation dynamics and determine the minimum period post application necessary to comply with the established commercial standards. The insecticides dichlorvos (DDVP), chlorpyrifosmethyl+deltamethrin (CPM) and pirimiphos-methyl (PMM) were applied to maize grains, which were then stored for 120 days. The samples were processed and extracted using the QuEChERS technique and the pesticide residues were identified and quantified by gas chromatography-mass spectrometry. Deltamethrin residues were not analized. After 90 days of storage, more than $80 \%$ of the initial residue had been degraded, and after 120 days the residues were below the detection limit (LOD). DDVP, CPM and PMM residues followed a first order degradation dynamics $\left[\mathrm{C}_{\mathrm{f}}=\mathrm{C}_{0} \times \mathrm{e}^{(-\mathrm{kt})}\right]$, with $\mathrm{k}$ values of $0.384,0.025$ and 0.020 and estimated half-lives of $1.8,27.7$ and 34.7 days, respectively. These results show that at recommended dosages, the insecticides CPM and PMM are safe for use on stored maize grains; DDVP results provide additional evidence further reasserting its prohibition, which dates back to 2018.
\end{abstract}

Key words: postharvest, grains, degradation kinetics, dichlorvos, chlorpyrifosmethyl, pirimiphos-methyl, residues

Strada, J., Bruno, C., Nassetta, M. M., Balzarini, M. G., Conles, M. Y., Rojas, D., Ricca, A. P., Cristos, D. y Martinez, M. J. 2021. Evaluación de la degradación de residuos de insecticidas organofosforados en granos de maíz (Zea mays L.) almacenados. Agriscientia 38 (2): 53-61

\section{RESUMEN}

Los objetivos del trabajo fueron monitorear la degradación de insecticidas organofosforados aplicados a granos de maíz almacenados en ensayos experimentales, establecer las dinámicas de degradación y determinar el tiempo mínimo de espera post aplicación necesario para cumplir con los 
estándares comerciales. Se aplicaron los insecticidas diclorvós (DDVP), clorpirifós-metil+deltametrina (CPM) y pirimifós-metil (PMM) a granos de maíz almacenados durante 120 días. Las muestras se procesaron y extrajeron mediante la técnica QuEChERS y los residuos de plaguicidas se identificaron y cuantificaron mediante cromatografía de gases-espectrometría de masas. Los residuos de deltametrina no fueron determinados. Luego de 90 días de almacenamiento, más del $80 \%$ del contenido inicial de residuos se había degradado y a los 120 días se encontraban por debajo del límite de detección (LoD). Los residuos de DDVP CPM y PMM siguieron una dinámica de degradación de primer orden $\left[\mathrm{C}_{\mathrm{t}}=\mathrm{C}_{0} \times \mathrm{e}^{(-\mathrm{kt})}\right]$, con valores de $\mathrm{k}$ de 0,384, 0,025 y 0,020 y vidas medias estimadas de $1 ; 8 ; 27,7$ y 34,7 días respectivamente. Estos resultados permiten concluir que a la dosis recomendada, los insecticidas CPM y PMM se pueden usar de manera segura en granos de maíz almacenados, mientras que los resultados de DDVP aportan información adicional que ratifica su prohibición, que data del año 2018.

Palabras clave: postcosecha, granos, dinámica de degradación, diclorvós, clorpirifós-metil, pirimifós-metil, residuos

Strada, J. (ORCID: 0000-0002-6144-978X) and Martinez, M. J. (ORCID: 0000-0002-0991-2378): Instituto Nacional de Tecnología Agropecuaria, Estación Experimental Agropecuaria. Manfredi, Córdoba, Argentina. Bruno, C. (ORCID: 0000-0002-3674-7128), Balzarini, M. G. (ORCID: 0000-0002-4858-4637) and Conles, M. Y. (ORCID: 0000-0002-8763-9100): Universidad Nacional de Córdoba, Facultad de Ciencias Agropecuarias and UFYMA CONICET, Córdoba, Argentina. Nassetta, M. M. (ORCID: 90000-0003-1372-6137): CEPROCOR, MINCYT Provincia de Córdoba, Argentina. Rojas, D. (ORCID: 0000-0002-4189-6662) and Cristos, D. (ORCID: 0000-00028763-9100): Instituto Nacional de Tecnología Agropecuaria, Instituto de Tecnología de Alimentos, Hurlingham, Buenos Aires, Argentina. Ricca, A. P. (ORCID: 0000-0003-1799-1130): Instituto Nacional de Tecnología Agropecuaria, Estación Experimental Agropecuaria, Área Metropolitana de Buenos Aires, Argentina. Correspondence to: martinez.mariajose@inta.gob.ar

\section{INTRODUCTION}

Argentina is one of the world leaders in maize (Zea mays L.) production, occupying the fourth place as producer with more than 56 Mt in 2019 and the third place as exporter after Brazil and USA with $36 \mathrm{Mt}$ (FAO Stat, 2020). In the last 30 years, maize yields in Argentina have increased at a rate of $159 \mathrm{~kg} \cdot \mathrm{ha}^{-1} . \mathrm{yr}^{-1}$. In this country, maize cultivation is of great importance, due to the large cultivated area, annual production volume and multiple uses for human and animal consumption or industrialization. Most of the production is exported, providing important foreign currency revenues to the country.

During storage, maize grains can be attacked by insects, which are controlled using preventive measures, such as spraying with organophosphate and pyrethroid insecticides (Abadia and Bartosik, 2013). However, to avoid the presence of residues in grains above the Maximum Residue Limits (MRLs) legally allowed both by the Argentinian regulations from Servicio Nacional de Sanidad y Calidad Agroalimentaria (SENASA, 2010) and by the international regulations of the Codex alimentarius (2020), insecticides should be applied appropriately. Thus, information about the dissipation kinetics of pesticides in crops is a key aspect in preventing risks and reducing the impact on health and trade. More restrictive MRLs in the exportation markets create obstacles to maize trade in big markets, such as the Europeans. Therefore, studies that include the analysis of residue dynamics in food are essential to support production and take decisions. The most used model for this is a pseudo-first-order kinetic model (Fantke and Juraske, 2013). For this type of model, 
it is also important to calculate the maximum residual concentrations that can be allowed in food for safe human or animal consumption according to the MRLs. The minimum period of time between pesticide application and consumption is called "post-harvest interval" (POHI) and is defined as the time in days established between the last application in storage and consumption of the agricultural products. The requirements have determined that grains shall be completely free from insects but contain residues of no more than one tenth or less of the MRLs (Fleurat-Lessard et al., 1998). PMM and CPM are registered in Argentina for application in stored grains. Regarding DDVP, in 2018 SENASA through Resolution No 149/2018 prohibited the importation, commercialization and use of the active principle and products that contain it for use in grains. This prohibition came as a response to the widespread use of DDVP in Argentina which established much higher MRLs than those required by the purchasing countries. Even though this active principle is banned in Argentina and its use restricted to only some agricultural products in foreign legislation, the results of this work can be considered an important contribution on the dynamics of residues degradation. The dissipation of insecticide residues in other cereal grains, like wheat, has been extensively studied ( $\mathrm{Pal}$ and Shah, 2008; Uygun et al., 2008; Lucini and Molinari, 2011), but that for maize is poorly known (Alleoni and de Baptista, 2001; Hamacher at al., 2002; Sgarbiero et al., 2003; Silveira et al., 2009). Pesticide trading companies must carry out tests to determine the $\mathrm{POHI}$ necessary to reach values below the MRL, but their studies are not available to estimate the residue levels after a pre-market application. Since MRLs vary among different markets, they turn out to act as barriers to trade. As respects storage grains, for SENASA (2021) there is not a "post-harvest interval" (POHI) for PMM and CPM but in the case of grain production for exportation, the Limit of Maximun Residue in the country must be known and the application periods of these pesticides must be adapted to them. For CPM a period of 20-30 hours is recommended before the consumption. Regarding DDVP there is not a grace period since it is banned, but in the past it used to be 20 to 30 days. The information about the MRLs in Argentina, European Union (EU) and the Codex Alimentarius are available (Global MRL database, 2020; European Union Pesticides database, 2020; SENASA, 2021). The surface characteristics and the physical and chemical properties of the grain tegument of different cereals are very different and thus specific degradation models are required to describe the degradation of pesticide residues in a specific cereal, stored in a specific country (Fleurat-Lessard et al., 1998).

Thus, the aims of this work were to monitor the degradation dynamics of the organophosphate insecticides applied to stored maize grains in Argentina, to establish the first order kinetics and to determine the $\mathrm{POH}$ necessary to comply with different standards.

\section{MATERIALS AND METHODS}

\section{Supervised experimental trials and analysis of pesticide residues}

The experimental field assays were carried out during 120 days at Instituto Nacional de Tecnología Agropecuaria at the Estación Experimental Agropecuaria Manfredi (EEA INTA Manfredi), Córdoba province, Argentina. A completely randomized experimental design was used to simulate the typical grain storage conditions in Argentina. Three separate maize grain lots $(13 \mathrm{~kg})$ were treated with each pesticide and other three grain lots of the same size were used as controls (untreated). All lots were sampled at different time points to quantify the pesticides residues. The organophosphate insecticides formulated as emulsifiable concentrates were evaluated on the maize supervised experimental trials. The concentrations (and rates in $\mu \mathrm{g}$ of active ingredient per $\mathrm{g}$ of grain) were $100 \%$ (20 $\mu \mathrm{g}$ per g) for dichlorvos (DDVP), $14.5 \%+0.65 \%(2.9 \mu \mathrm{g}$ per g) for chlorpyrifos-methyl + deltamethrin respectively (CPM), and $50 \%$ ( $5 \mu \mathrm{g}$ per g) for pirimiphos-methyl (PMM). The maize grains were treated with the rates indicated in the labels of the commercial products used.

For insecticide application, maize grains were spread in a layer, on a $100 \mu \mathrm{m}$ polyethylene sheet for a homogeneous insecticide distribution; insecticides were applied using a hand 1.5। Giber sprayer (Giber SA, Argentina). The flow was previously tested with water. The grains were vigorously mixed, placed inside the duly labeled plastic containers, capped and stored. The lids were perforated to allow gas exchange.

The plastic containers were placed in shelves inside a room conditioned for grain storage. During the experimental assay, room temperature and relative humidity $(\mathrm{RH})$ were maintained in relatively controlled conditions (within 20 to $25^{\circ} \mathrm{C}$ and 40 to $60 \% \mathrm{RH})$.

The objective of the study was to put the samples in conditions similar to the real ones. Grain moisture content was $14 \%$. Samples $(500 \mathrm{~g})$ were collected 
from each lot with a bag trier at 2, 30, 60, 90 and 120 days after application, placed in three-layered bags and taken to a freezer at $-20^{\circ} \mathrm{C}$ until further analysis.

Grain samples were processed at the Laboratorio de Calidad de Granos at EEA INTAManfredi, Argentina. The milling was done with glass blenders. Insecticides were extracted from grains by using the QuEChERS technique (Anastassiades et al., 2003; Lehotay, 2007) adapted to dry matrices (Mastovska et al., 2010; Lucini and Molinari, 2011). Each sample (5 g) was extracted in a centrifuge tube by adding water $(10 \mathrm{~mL})$ and acetonitrile $(15 \mathrm{~mL})$ and $150 \mu \mathrm{L}$ of internal standard solution of ethoprophos $\left(20 \mu \mathrm{g} \cdot \mathrm{mL}^{-1}\right), 6 \mathrm{~g}$ of anhydrous magnesium sulfate and $1.5 \mathrm{~g}$ of sodium chloride. The extract was then homogenized and centrifuged ( $\left.R C F=5000 \mathrm{~g}, 5^{\circ} \mathrm{C}, 5 \mathrm{~min}\right)$. An aliquot $(5 \mathrm{~mL}$ ) of the organic phase supernatant was transferred to a clean-up tube containing $0.75 \mathrm{~g}$ of anhydrous magnesium sulfate, $0.2 \mathrm{~g}$ of bonded silica bulk, primary or secondary amine SUPELCO $40 \mathrm{um}$ (PSA) and $0.2 \mathrm{~g}$ of $\mathrm{C}_{18}$, and then shaken and centrifuged $\left(\mathrm{RCF}=5000 \mathrm{~g}, 5^{\circ} \mathrm{C}, 5 \mathrm{~min}\right)$. An aliquot of the supernatant $(2 \mathrm{~mL})$ was transferred and evaporated to dryness under a stream of nitrogen with the water bath set at $35^{\circ} \mathrm{C}$. The sample was recovered with toluene $(500 \mu \mathrm{L})$ and shaken; $300 \mu \mathrm{L}$ was collected and placed in a vial. Then, $50 \mu \mathrm{L}$ of Triphenylphosphate (TPP) solution $\left(2 \mu \mathrm{g} \cdot \mathrm{mL}^{-1}\right)$ and $25 \mu \mathrm{L}$ of toluene were added. Blank samples (without matrix with insecticide mixture) and fortified samples (with matrix and insecticide mixture) were prepared for quality control of the extraction technique.

Validations were also performed using calibration tests, matrix effect studies and recovery experiments to define the linear dynamic range and calculate recovery, expanded uncertainty, and limits of detection (LoD) and limits of quantification (LoQ). Recovery data were used to assess the accuracy and precision of the method (Document SANCO 10684/2009). Standard solutions of all the active pesticide compounds used in this study were prepared for validation assays by using stock solution concentrations of $1 \mathrm{mg} \cdot \mathrm{mL}^{-1}$ for DDVP, PMM and CPM, and $2 \mathrm{mg} \cdot \mathrm{mL}^{-1}$ for ethoprophos and TPP to derive working solutions. The fortification levels used for DDVP and PMM were 0.01, 0.05, 0.1, 1, 3 and $9 \mu \mathrm{g}^{-1}{ }^{-1}$, whereas those for CPM were 0.01 , $0.05,0.1,1$ and $3 \mu \mathrm{g} \cdot \mathrm{g}^{-1}$, using a matrix of organic maize flour ( $5 \mathrm{~g}$ ) and three replicate tests per level.

Pesticide residues from maize samples of supervised experimental trials were identified and quantified by high-resolution gas chromatography coupled to mass spectrometry (GC-MS) at the
Laboratorio de Contaminantes Químicos of the Instituto de Tecnología de los Alimentos of INTA Castelar. Deltamethrin residue insecticide that was applied to the corn storage grains treatment, was neither able to be identified nor quantified.

A Perkin Elmer Clarus 600 gas chromatograph, with programmable temperature vaporizer (PTV) injection port was used in order to separate, identify and quantify each insecticide analyte. The PTV temperature program used was $35^{\circ} \mathrm{C}(4 \mathrm{~min})$, then it was raised to $290^{\circ} \mathrm{C}\left(200^{\circ} \mathrm{C}-\mathrm{min}^{-1}\right.$ for $\left.4.5 \mathrm{~min}\right)$, and finally reduced to $35^{\circ} \mathrm{C}\left(60^{\circ} \mathrm{C} \cdot \mathrm{min}^{-1}\right)$. The injection volume was $25 \mu \mathrm{l}$ : For separation of each analyte a Guard column fused silica of $5 \mathrm{~m} \times 0.25 \mathrm{~mm}$ (Supelco) with a Capillary column (Varian, Factor Four VF-5ms), $30 \mathrm{~m} \times 0.25 \mathrm{~mm}$ (id, $0.25 \mu \mathrm{m}$ ). Helium of $99.999 \%$ purity was used as gas carrier. The initial pressure was 2 psi (3.9 min), reached 25 psi (at 25 psi.min-1 for $7 \mathrm{~min}$ ), and then decreased to 15 psi (at 25 psi.min $^{-1}$ ), which was maintained until the end of the assay (35 min). The initial split flow was $100 \mathrm{ml} \cdot \mathrm{min}^{-1}$; the flow was closed at min $3.9\left(0 \mathrm{ml} \cdot \mathrm{min}^{-1}\right)$ and at min 10 , the flow was set at $20 \mathrm{ml} \cdot \mathrm{min}^{-1}$. The oven temperature program used was $70^{\circ} \mathrm{C}(8 \mathrm{~min})$, increased to $170^{\circ} \mathrm{C}\left(25^{\circ} \mathrm{C} \cdot \mathrm{min}^{-1}\right)$, $230{ }^{\circ} \mathrm{C}\left(5^{\circ} \mathrm{C} \cdot \mathrm{min}^{-1}\right)$, reaching a maximum of $290^{\circ} \mathrm{C}$ (at $20^{\circ} \mathrm{C} \cdot \mathrm{min}^{-1}$ ) which was held for 10 minutes. The transfer line in the detector was held at $290^{\circ} \mathrm{C}$ and the collision cell at $200^{\circ} \mathrm{C}$. Cromatographic data were obtained by electron impact $(\mathrm{El}+)$, quadropole analyzer and monitoring of specific ions (SIM, selected ion monitoring), one ion for quantitation and at least two for qualification for each analyte. Highpurity analyte standards from Sigma Aldrich (USA) were used for validation assays and quality control of the extraction process: dichlorvos (99.9\%), chlorpyrifos-methyl (99.9\%) and pirimiphos-methyl $(99.5 \%)$; and the internal standards ethoprophos (93.1\%) and triphenylphosphate (TPP) (99\%). Control samples (organic maize flour) were used for validation assays and as quality control of the extraction process. DDVP, CPM and PMM residues were recorded. The results of the analyses are expressed in micrograms of the DDVP, CPM and PMM insecticides per gram of grains $\left(\mu g \cdot g^{-1}\right)$.

\section{Statistical analyses}

The daily dissipation rate (DDR) was calculated considering the decrease in the level of residues within two successive analytical determinations. A generalized linear mixed model with gamma distribution and logarithmic link function was adjusted to evaluate the effect of the days after application on the degradation of each insecticide. 
The model included a random effect to induce experimental unit correlations between repeated measurements of the same lots of grains. The dynamics of the residues according to the days after application (dissipation kinetics) was modeled by the first-order kinetic model:

$$
\mathrm{C}_{\mathrm{t}}=\mathrm{C}_{0} \times \mathrm{e}^{\left(-\mathrm{K}_{\mathrm{t}} \mathrm{t}\right)} \text { Eq. (1) }
$$

where $\mathrm{C}_{\mathrm{t}}$ is the residue concentration at time $t, C_{0}$ is the initial concentration or nominal rate, and $\mathrm{K}$ is the dissipation constant. The parameters estimated $\left(\mathrm{C}_{0}\right.$ and $\left.\mathrm{K}\right)$ were used to calculate using Eq. (2). Analyses were performed using the statistical software InfoStat (Di Rienzo et al., 2019).

$$
\mathrm{HL} \text { or } \mathrm{t}_{1 / 2} \text { (days) }=\ln 2 . \mathrm{K}^{-1} \quad \text { Eq. (2) }
$$

\section{RESULTS AND DISCUSSIONS}

\section{Validation of the QuEChERS+GC-MS methodology}

The values of average recovery, relative standard deviation, expanded uncertainty, LOD and LOQ for DDVP, CPM and PMM by using QuEChERS+CGMS are shown in Table 1. An effect of the matrix was observed for all analytes and the quantification was performed through calibration curves in the matrix, which were linear for the concentration range studied $\left(R^{2}>0.98\right)$ (Document SANCO 10684/2009).

Mean recovery values for the three insecticides were greater than $70 \%$, with adequate reproducibility. These results are consistent with previous validation of QuEChERS in cereal grains (Mastovska et al., 2010; Lucini and Molinari, 2011; Yu et al., 2014). The validation assays showed no residues in the control samples during the extraction process. Thus, we inferred that the process quality was adequate.

\section{Dynamics of insecticide residues}

All the treated samples showed residues of the insecticides studied, whereas the untreated control samples were negative for residues. The curves describing the expected dynamics for the three insecticides are presented in Figure 1. The mean residue levels obtained in maize grains at 2, 30, 60, 90 and 120 days after application, the DDR, and the residue decline (\%), estimated by the pseudo-first-order kinetic model, are presented in Table 2. The equations representing the dissipation dynamics are shown in Table 3.

DDVP, CPM and PMM residues showed lower levels as the number of days after application increased (Table 2), in response to a first-order kinetics, with high coefficient of determination $\left(R^{2}\right)$ (Table 3). The number of days after application had a statistically significant effect $(p<0.05)$ on the levels of residues present in the grains for the three insecticides, with residues below the LoQ at 120 days (Table 2). The dissipation kinetics has three phases: the first or "stripping phase", which is due mainly to mechanical causes not involved in storage trails (wind and rain); the "degradation phase", which is due to physical and chemical causes; and the "persistence phase", which is determined by

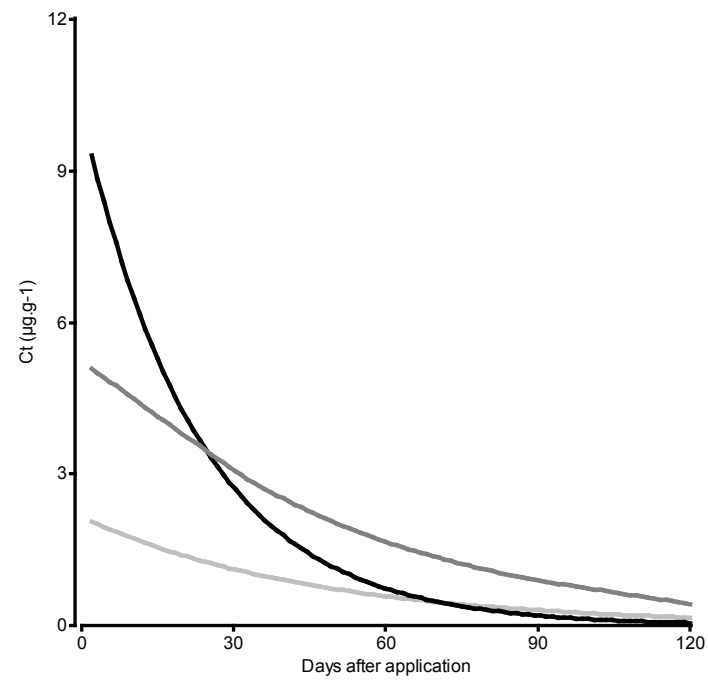

Figure 1. Curves describing the expected dynamics for dichlorvos $(-)$, pirimiphos-methyl ( - ) and chlorpyrifos- methyl ( $(-)$ applied in stored maize grains

Table 1. Parameters obtained during analytical method validation for dichlorvos (DDVP), chlorpyrifos-methyl (CPM) and pirimiphosmethyl (PMM) in stored maize grains

\begin{tabular}{lcccccccc}
\hline Insecticides & $\begin{array}{c}\text { Spiked } \\
\text { level }\left(\mu \mathrm{gg} \cdot \mathrm{g}^{-1}\right)\end{array}$ & $\begin{array}{c}\text { Average } \\
\text { recovery }(\%)\end{array}$ & $\begin{array}{c}\mathrm{RSD} \\
(\%)\end{array}$ & $\begin{array}{c}\text { LoD } \\
\left(\mu \mathrm{g} \cdot \mathrm{g}^{-1}\right)\end{array}$ & $\begin{array}{c}\mathrm{LoQ} \\
\left(\mu \mathrm{gg} \cdot \mathrm{g}^{-1}\right)\end{array}$ & Regression equation & $\mathrm{R}^{2}$ & $\begin{array}{c}\mathrm{U} \\
(\%)\end{array}$ \\
\hline DDVP & $0.01-9.00$ & $78.0-102.8$ & $6.6-13.1$ & 0.003 & 0.01 & $\mathrm{y}=0.37 \times-0.04$ & 0.99 & $13.1-26.2$ \\
CPM & $0.01-3.00$ & $78.0-99.9$ & $10.3-20.0$ & 0.003 & 0.01 & $\mathrm{y}=0.81 \times-0.06$ & 0.98 & $20.5-31.8$ \\
PMM & $0.01-9.00$ & $70.0-95.7$ & $2.3-25.0$ & 0.003 & 0.01 & $y=0.95 \times+0.27$ & 0.99 & $4.6-24.8$ \\
\hline
\end{tabular}

References: relative standard deviation (RSD), limit of detection (LoD), limit of quantification (LoQ), expanded uncertainty (U). 
Table 2. Degradation parameters of dichlorvos (DDVP), chlorpyrifos-methyl (CPM) and pirimiphos-methyl (PMM) in stored maize grains obtained in experimental assays

\begin{tabular}{|c|c|c|c|c|c|c|}
\hline \multirow[t]{2}{*}{ Variable } & \multirow[t]{2}{*}{ Insecticides } & \multicolumn{5}{|c|}{ Days after application } \\
\hline & & 2 & 30 & 60 & 90 & 120 \\
\hline Residues & DDVP & 9.27 & 2.97 & 0.38 & 0.02 & $<\mathrm{LoQ}$ \\
\hline \multirow[t]{2}{*}{$\left(\mu g \cdot g^{-1}\right)$} & CPM & 1.98 & 1.29 & 0.67 & 0.10 & $<\mathrm{LOQ}$ \\
\hline & PMM & 5.10 & 3.54 & 1.52 & 0.72 & $<\mathrm{LoQ}$ \\
\hline DDR & DDVP & 0.2250 & 0.0860 & 0.0120 & 0.0010 & --- \\
\hline \multirow[t]{2}{*}{$\left(\mu \mathrm{g} \cdot \mathrm{g}^{-1} \cdot \mathrm{day}^{-1}\right)$} & CPM & 0.0250 & 0.0210 & 0.0190 & 0.0030 & --- \\
\hline & PMM & 0.0560 & 0.0670 & 0.0027 & 0.0024 & --- \\
\hline \multirow{3}{*}{$\begin{array}{l}\text { Residue decline } \\
(\%)\end{array}$} & DDVP & ND & 68.0 & 95.9 & 99.8 & 100.0 \\
\hline & CPM & ND & 34.8 & 66.2 & 94.9 & 100.0 \\
\hline & PMM & ND & 30.6 & 70.2 & 85.9 & 100.0 \\
\hline
\end{tabular}

References: daily dissipation rate $(\mathrm{DDR}),<\mathrm{LOQ}=$ below limit of quantification. Nominal rate: $20 \mu \mathrm{g} \cdot \mathrm{g}^{-1}$ for DDVP, $2.9 \mu \mathrm{g} . \mathrm{g}^{-1}$ for $\mathrm{CPM}$ and $5 \mu \mathrm{g} \cdot \mathrm{g}^{-1}$ for PMM.SD: no data.

Table 3. Equations for first-order kinetics of residue dynamics, for dichlorvos (DDVP), chlorpyrifos-methyl (CPM) and pirimiphosmethyl (PMM) in stored maize grains

\begin{tabular}{lccc}
\hline Insecticide & Kinetics equation & $\mathrm{R}^{2}$ & $\mathrm{HL}$ or $\mathrm{t}_{1 / 2}$ (days) \\
\hline DDVP & $\mathrm{Ct}=20 \times \mathrm{e}^{-0.384 \mathrm{t}}$ & 0.97 & 1.8 \\
CPM & $\mathrm{Ct}=2.54 \times \mathrm{e}^{-0.025 \mathrm{t}}$ & 0.88 & 27.7 \\
PMM & $\mathrm{Ct}=5.27 \times \mathrm{e}^{-0.020 \mathrm{t}}$ & 0.78 & 34.7 \\
\hline
\end{tabular}

References: coefficient of determination $\left(\mathrm{R}^{2}\right)$ and half-life $\left(\mathrm{HL}-\mathrm{t}_{1 / 2}\right)$.

the retention residues in the material. In our study, the second and third phases were recognized for all insecticides.

With respect to experimental DDR, the number of days after application had a statistically significant effect $(p<0.05)$ on the levels of residues present in the grains for DDVP and PMM. The DDR for PMM were different until 60 days after application, whereas those for CPM were not statistically different. The apparent rates of degradation in the initial storage period were higher than those in the later stages. The values of DDR inferred from the fitted model were similar to the experimental ones in the case of PMM and CPM.

For DDVP, the DDR were high up to 30 days after application, which corresponds to the "degradation phase" of residues, whereas after that period, DDR decreased (Table 2). The K coefficient was 0.384 for DDVP, 0.025 for CPM and 0.020 for PMM (Table 3). For all the insecticides, 90 days after application, experimental residues showed a clear decline (Figure 2). The calculated HL was higher for PMM than for CPM and lowest for DDVP (Table 3).

The first-order degradation kinetics has been previously reported in other matrices for DDVP, CPM and PMM (Fleurat-Lessardet al., 1998; El-Behissy et al., 2001; Yu et al., 2014). In wheat and oat grains treated with PMM, for example, Lucini and Molinari (2011) did not detect residue degradation,

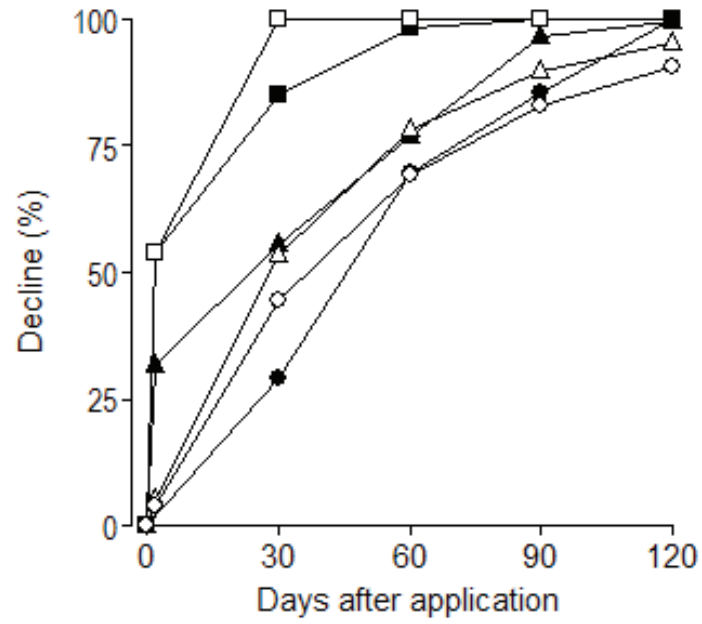

Figure 2. Experimental residue decline (\%) of dichlorvos ( chlorpyrifos- methyl $(\boldsymbol{\Lambda})$ and pirimiphos-methyl $(\bullet)$ and estimated decline of dichlorvos $(\square)$, chlorpyrifos- methyl $(\Delta)$ and pirimiphosmethyl (O) in maize grains at 2, 30, 60, 90 and 120 days after application

whereas in maize stored for 18 months. White et al. (1997) found similar results. In rice, Yu et al. (2014) determined $\mathrm{K}$ coefficient of 0.384 for DDVP, 0.025 for CPM and 0.020 for PPM.

In wheat, other authors found lower values for CPM, between 0.0038 and 0.0072 (Fleurat-Lessard et al., 1998; Pal and Shah, 2008). In the present study, the first-order kinetics for DDVP showed high average $\mathrm{K}$ coefficients, in agreement with results reported by other authors working with this insecticide (El-Behissy et al., 2001). The high value of $\mathrm{K}$ for DDVP may respond to the high volatility of this insecticide (El-Behissy, et al. 2001), which corresponds to a short period of protection. Then, the fitted model should be used to predict the 
behavior of residues only in the initial stages of dissipation.

The residue decline $(85 \%)$ was consistent with other findings in cereal grains (Sgarbiero et al., 2003; Silveira et al., 2009; Strada et al., 2012), and in agreement with the physico-chemical characteristics of each active ingredient, as reported by Balinova et al. (2006). These authors determined that, after 90 days of storage of wheat, CPM residues decreased by $60 \%$ and that PMM residues decreased by only $30 \%$. This decrease in PPM residues observed in maize 90 days after application was in consonance with the decrease observed by Hamacher et al. (2002) in wheat after 126 days of storage and by Yu et al. (2014) in rice after 60 days of storage. Fantke and Juraske (2013) determined that organophosphate pesticides have high variability in $\mathrm{HL}$ ( 0.7 to 55 days). In our study, the average half-life ( $\mathrm{HL}$ or $\mathrm{t}_{1 / 2}$ in days) of each insecticide in stored maize grains was higher for PMM than for CPM and the lowest for DDVP. In contrast, there has been slower dissipation of PMM residues reported in wheat (between 100 and 490 days) by Holland, Hamilton, Ohlim and Skidmore,1994 and in maize (between 85 and 95 days) by Alleoni and de Baptista, 2001 and Sgarbiero et al., 2003.

Yu et al. (2014) reported HL values for PMM between 27 and 29 days in rice, where as other authors reported $\mathrm{HL}$ values lower than 14 days for DDVP in different matrices (Holland et al., 1994; El Behissy et al., 2001). In our study, DDVP was the insecticide with highest dissipation (1.8 days). Regarding CPM, the HL reported in stored wheat grains is of 60-70 days (Pal and Shah, 2008) or 93-169 days, depending on the grain moisture (Fleurat-Lessard et al., 1998; Holland et al., 1994). All these results confirm that the $\mathrm{HL}$ estimated for a pesticide depends on the matrix studied, the active ingredient, the application rate, and the environmental conditions during storage, and the grain moisture content. Likewise, the residue decline is slower when the insecticide is applied on stored products (Holland et al., 1994; Balinova et al., 2006) than on crops in the field, with residue persistence (Lucini and Molinari, 2011).

The MRLs for PMM according to the different legislation are: SENASA, $10 \mu \mathrm{g} \cdot \mathrm{g}^{-1}$, Codex Alimentarius, $7 \mu \mathrm{g} \cdot \mathrm{g}^{-1}$ for PMM on storage grains and UE legislation, $0.5 \mu \mathrm{g} \cdot \mathrm{g}^{-1}$.

In the same way, the MRLs for CPM are $5 \mu \mathrm{g} \cdot \mathrm{g}^{-1}$ according to SENASA and $0.01 \mu \mathrm{g} \cdot \mathrm{g}^{-1}$ according to EU legislation. The MRLs for DDVP are: following the Codex Alimentarius, $7 \mu \mathrm{g} . \mathrm{g}^{-1}$ for DDVP (in rice and wheat) and following EU legislation, $0.01 \mu \mathrm{g} \cdot \mathrm{g}^{-1}$ for DDVP EU pesticide database, 2020.

Some works conducted in stored grains have reported that storage is not efficient to reduce insecticide residues below the permitted MRLs (Uygun et al., 2008).

The results of our study suggest that the residues of PMM in maize grains under the storage conditions commonly used in Argentina do not exceed the MRLs established by SENASA and the Codex Alimentarius. In the present study, the PMM residues found two days after application were below the MRLs established in Argentina and suggested by the Codex Alimentarius; however, the values exceeded those established by the EU.

CPM residues were below the MRLs established in Argentina two days after application. With respect to $\mathrm{CPM}$ the $\mathrm{POHI}$ within the limits by SENASA. $\mathrm{POHI}$ to reach residue values experimentally established by the EU $\left(0.01 \mu \mathrm{g}^{-1} \mathrm{~g}^{-1}\right)$ is 110 days for CPM and DDVP. Then, grains destined for this market should not be treated with these insecticides (Abadia and Bartosik, 2013).

\section{CONCLUSIONS}

A first-order kinetic model allowed explaining the decline of residue levels of DDVP, CPM and PMM applied for insect control on stored maize grains, with levels below the LoQ being found at 120 days. The half-lives of insecticide residues and DDR varied among these organophosphate pesticides. Regarding the $\mathrm{POHI}$ required for residues to reach the MRLs, the three insecticides exceeded the EU MRLs, whereas PMM and DDVP are in accordance with the regulations of Argentina and the Codex Alimentarius, because the residue levels were within the tolerated. Therefore, the results lead to the conclusion that, at the recommended dosage, the use of the insecticides PMM and CPM will be recommended in maize grains considering the LMR by SENASA. The knowledge of the dissipation curves in these three insecticides allows us to predict the $\mathrm{POHI}$ necessary to attain a certain level of residues in order to comply with current legislation.

\section{ACKNOWLEDGEMENTS}

This study was part of the PE I 147 Inocuidad; PNCER 023531 and PNCYO 1127022 projects supported by Instituto Nacional de Tecnología Agropecuaria, Argentina and CONICET. 


\section{REFERENCES}

Abadia, B. and Bartosik, R. (Eds.) (2014). Manual de buenas prácticas en poscosecha de granos: Hacia el agregado de valor en origen de la producción agropecuaria. INTA, Ministerio de Agricultura, Ganaderíay Pesca. Presidencia de la Nación Argentina. https://es.scribd.com/document/258244726/Manualde-Buenas-Practicas-en-Poscosecha-de-Granos

Alleoni, B. and de Baptista, G. C. (2001). Resíduos de malation e pirimifós-metil em grãos de milho (Zea mays L.) determinados por cromatografia em fase gasosa. Revista Brasileira de Toxicologia, 14, 17-22.

Anastassiades, M., Lehotay, S. J., Stajnbaher, D. and Schenck, F. J. (2003). Fast and easy multiresidue method employing acetonitrile extraction/partitioning and "dispersive solid-phase extraction" for the determination of pesticide residues in produce. Journal of Association of Official Analytical Chemists International, 86(2), 412-431. https://pubmed.ncbi. nlm.nih.gov/12723926

Balinova, A. M., Mladenova, R. I., and Shtereva, D. D. (2006) Effects of processing on pesticide residues in peaches intended for baby food, Food Additives \& Contaminants, 23(9), 895-901. https://doi. org/10.1080/02652030600771715

Cámara Argentina de Sanidad Agropecuaria y Fertilizantes (CASAFE, 2020). Guía de Productos Fitosanitarios para la República Argentina 2015/2017. https://guiaonline.casafe.org

Codex alimentarius. Retrieved in 2020: http://www.fao. org/fao-who-codexalimentarius/codex-texts/dbs/ pestres/pesticides/es/

Di Rienzo, J. A., Casanoves, F., Balzarini, M. G., Gonzalez, L., Tablada, M. and Robledo, C. W. InfoStat (versión 2019) [Software]. Córdoba, Argentina: Grupo InfoStat, FCA, Universidad Nacional de Córdoba. http://www. infostat.com.ar

European Union. Pesticides Database (n. d.). https:// ec.europa.eu/food/plant/pesticides/eu-pesticidesdb_en (n. d.)

European Union (2009). Document N SANCO 10684. Method validation and quality control procedures for pesticide residues analysis in food and feed. https://www.eurl-pesticides.eu//library/docs/allcrl/ AqcGuidance_Sanco_2009_10684.pdf

El-Behissy, E. Y., King, R. D., Ahmed, M. M. and Youssef, A. M. (2001). Fate of postharvest-applied dichlorvos in stored and processed dates. Journal of Agricultural and Food Chemistry, 49(3), 1239-1245. https://doi. org/10.1021/jf000812e

Fantke, P. and Juraske, R. (2013). Variability of pesticide dissipation half-lives in plants. Environmental Science and Technology, 47(8), 3548-3562.
FAOStat (2020). Statistical Division of Food and Agriculture Organization of the United Nations. https:// www.fao.org/faostat/es/\#data/QV

Fleurat-Lessard, F., Vidal, M. L. and Budzinski, H. (1998). Modelling biological efficacy decrease and rate of degradation of chlorpyrifos-methyl on wheat stored under controlled conditions. Journal of Stored Products Research, 34(4), 341-354. https://doi.org/10.1016/ S0022-474X(98)00013-7

Global MRL database (2020). Bryant Christie Inc. https:// bcglobal.bryantchristie.com/db\#pesticides/query

Hamacher, L. S., Faroni, L. R. D., Guedes, R. N. C. and Queiroz, M. E. L. R. (2002). Persistence and activity towards Sitophilus zeamais (Coleóptera: Curculionidae) of pirimiphos-methyl sprayed at different temperatures on maize. Journal of Stored Products Research, 38(2), 167-175. https://doi. org/10.1016/S0022-474X(01)00014-5

Holland, P., Hamilton, D., Ohlim, B. and Skidmore, M. (1994). Effects of storage and processing on pesticide residues in plant products. Pure and Applied Chemistry, 66(2), 335-356. https://doi.org/10.1351/ pac199466020335

Lehotay, S. J. (2007). Determination of pesticide residues in foods by acetonitrile extraction and partitioning with magnesium sulfate: collaborative study. Journal - Association of Official Analytical Chemists International, 90(2), 485-520.

Lucini, L. and Molinari, G. P. (2011). Residues of pirimiphos-methyl in cereals and processed fractions following post-harvest spray application. Journal of Environmental Science and Health Part B Pesticides Food Contaminants and Agricultural Wastes, 46(6), 518-524.

Mastovska, K., Dorweiler, K. J., Lehotay, S. J., Wegscheid, J. S. and Szpylka, K. A. (2010). Pesticides multiresidue analysis in cereal grains using modified QuEChERS method combined with automated direct sample introduction GC-TOFMS and UPLC-MS/MS techniques. Journal of Agricultural Food and Chemistry, 58(10), 5959-5972. https://doi.org/10.1021/jf9029892

Pal, P. and Shah, P. G. (2008). Effect of storage and processing on dissipation of five insecticides on wheat. Pesticide Research Journal, 20(2), 253-258.

Servicio Nacional de Sanidad y Calidad Agroalimentaria (SENASA, 2010). Resolución 934/2010. http://www.senasa.gob.ar/normativas/ resolucion-934-2010-senasa-servicio-nacional-desanidad-y-calidad-agroalimentaria

Servicio Nacional de Sanidad y Calidad Agroalimentaria (SENASA, 2018). Resolución 149/2018. http://www.senasa.gob.ar/normativas/ resolucion-149-2018-senasa-servicio-nacional-desanidad-y-calidad-agroalimentaria 
Servicio Nacional de Sanidad y Calidad Agroalimentaria (SENASA, 2021). Límites máximos de resíduos de plaguicidas (LMR). http://www. senasa.gob.ar/normativas/resolucion-934-2010senasa-servicio-nacional-de-sanidad-y-calidadagroalimentaria.

Sgarbiero, E., Trevizan, L. R. and de Baptista, G. C. (2003). Pirimiphos-Methyl residues in corn and popcorn grains and some of their processed products and the insecticide action on the control of Sitophiluszeamais Mots (Coleoptera: Curculionidae). Neotropical Entomology, 32(4), 707-711. https://doi.org/10.1590/ S1519-566X2003000400024

Silveira, R. D., Faroni, L. R. A., Guedes, R. N. C., Quiroz, M. E. L. R. and Pimentel, M. A. G. (2009). Biological activity and persistance of pirimiphos-methyl applied to maize grain at different temperatures. Revista brasileira de Engenharia Agricola e Ambiental, 13(6), 729-733. https://doi.org/10.1590/S141543662009000600010

Strada, J., Ricca, A., Conles, M., Silva, M., Rojas, D.,
Casini, C., Piatti, F. and Martínez, M. J. (2012). Evaluación de residuos de plaguicidas en granos de maíz (Zea mays L.) y trigo (Triticum aestivum L.) posterior a la aplicación en el almacenamiento y en el campo. Interciencia, 37(6), 412-417.

Uygun, U., Senoz, B. and Koksel, H. (2008). Dissipation of organophosphate pesticides in wheat during pasta processing. Food Chemistry, 109(2), 355-360. https:/l doi.org/10.1016/j.foodchem.2007.12.048

White, N. D. G., Jayas, D. S. and Demiank, C. J. (1997). Degradation and biological impact of chlorpyrifosmethyl on stored wheat and pirimiphos-methyl on stored maize in western Canada. Journal of Stored Products Research, 33(2), 125-135. https://doi. org/10.1016/S0022-474X(96)00049-5

Yu, C., Li, Y., Zhang, Q., Zou, N., Gu, K., Li, X. and Pan, C. (2014). Decrease of pirimiphos-methyl and deltamethrin residues in stored rice with post-harvest treatment. International Journal of Environmental Research and Public Health, 11(5), 5372-5381. https:// doi.org/10.3390/ijerph110505372 